\title{
Production potential of beef cattle in tropical pastures: a review
}

\section{Potencial de produção de bovinos de corte em pastagens tropicais: revisão de literatura}

Rondineli Pavezzi Barbero ${ }^{*}$ (1) , Anna Carolina de Carvalho Ribeiro ${ }^{1}$ (1) , André Morais

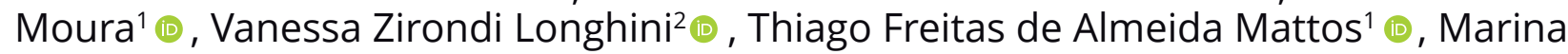
Mortati Dias Barbero ${ }^{1}$ (i)

\author{
${ }^{1}$ Universidade Federal Rural do Rio de Janeiro, Seropédica, RJ, Brazil \\ 2Universidade Estadual Paulista, Jaboticabal, SP, Brasil \\ *Correspondent: barbero.rp@gmail.com
}

Received

July 9, 2021.

Accepted

September 17, 2021.

Published

October 62021.

www.revistas.ufg.br/vet visit the website to get the how to cite in the article page.

\begin{abstract}
The expression production potential represents the maximum amount of products that can be obtained per unit area. However, what is the maximum amount of product that can be obtained in a pasture area? To answer this question, it is necessary to understand the factors related to forage accumulation, grazing efficiency, chemical composition of the forage plant, forage intake and nutritional requirements of animals, management, genetics, and management of the production system. The average annual productivity of beef cattle in Brazil is approximately $120 \mathrm{~kg}$ of body weight (approximately $60 \mathrm{~kg}$ of carcass) per hectare. This index is below the parameters reported in the literature. Adequate management of pastures with tropical forages usually provides a stocking rate above one animal unit (450 kg) per hectare. The increase in the stocking rate, combined with high individual body weight gain, provides high productivity, which may exceed $1260 \mathrm{~kg}$ of body weight (approximately 630 of carcass) per hectare per year. The production of beef cattle in tropical pastures has a high response potential with regard to the adoption of technologies to increase productivity indices.
\end{abstract}

Keywords: beef cattle, intensification, productivity, stocking rate, weight gain.

\section{Resumo}

O termo potencial de produção representa a quantidade máxima de produto que seria possível se obter em uma determinada área. Mas qual é o potencial de produção da bovinocultura de corte em pastagens tropicais? Para responder esta pergunta, é necessário compreender os fatores relacionados ao acúmulo de forragem, eficiência de pastejo, composição química da planta forrageira, consumo de forragem e requerimento nutricional dos animais para um dado 
desempenho, manejo, genética e gestão do sistema de produção. A produtividade média anual da pecuária de corte no Brasil está em torno de $120 \mathrm{~kg}$ de peso corporal (aproximadamente $60 \mathrm{~kg}$ de carcaça) por hectare. Este índice está bem abaixo de resultados reportados na literatura. O manejo adequado de pastagens com forrageiras tropicais normalmente proporciona taxa de lotação acima de uma unidade animal (UA, $450 \mathrm{~kg}$ ) por hectare. O aumento na taxa de lotação, combinado com elevado ganho de peso proporcionam alta produtividade, podendo ultrapassar $1260 \mathrm{~kg}$ de peso corporal (aproximadamente $630 \mathrm{~kg}$ de carcaça) anuais por hectare. A produção de bovinos de corte em pastagens tropicais possui alto potencial de resposta quanto a adoção de tecnologias para incremento nos índices de produtividade.

Palavras-chave: gado de corte, ganho de peso, intensificação, produtividade, taxa de lotação.

\section{Introduction}

It is widely known that the world's growing population is increasingly demanding more food. Considering that the arable area of the planet is relatively stable, to supply global demand, it will be necessary to increase agricultural productivity. According to the Brazilian Association of Meat Exporting Industries (ABIEC)(1), Brazil is the largest exporter and second-largest producer of beef in the world, with an average annual productivity of approximately $120 \mathrm{~kg}$ of body weight (approximately $60 \mathrm{~kg}$ of carcass) per hectare. This index is far below the values reported in the literature(2). However, what is the potential for the production of beef cattle in pastures?

To answer this question, it is necessary to understand that, in addition to health, genetics, and animal management, the potential for animal production in pastures is related to the potential for forage accumulation, nutritional value, and grazing efficiency. Forage accumulation is defined as the amount of forage produced. Grazing efficiency is the percentage of available forage that is effectively ingested by the animal(3). High forage accumulation with high grazing efficiency provides high support capacity, which is the amount of stocking that an area supports, with adequate production rates, and without going into degradation.

Increasing the stocking rate of pastures, respecting the support capacity, and observing high individual daily average weight gain generate high productivity per unit area. Beef cattle operation is an economic activity; in terms of income from production, the number of $\mathrm{kg}$ of body weight and carcass produced per hectare is a fundamental parameter of the production potential of cattle raised in pastures. The objective of the present work is to examine the factors related to the potential for livestock production in pastures and to present productivity parameters reported in the literature. 


\section{The main tropical forages used in Brazil}

\section{Genus and general characteristics}

Among the range of tropical forage genera in the market, the genus Urochloa (syn. Brachiaria), and Megathyrsus (syn. Panicum) are highlighted here because of their production potential in the tropical region of Brazil(4). The ability to adapt to different types of soil and fertility, as well as different climatic conditions, makes the Urochloa genus one of the most used in Brazil ${ }^{(5)}$. It is estimated that 90 million hectares of pasture are occupied by this genus in the country(6). In 1984, Marandu grass [U. brizantha (Hochst. ex A. Rich.) R.D. Webster cv. Marandu] was made available to the market as an alternative to replace $U$. decumbens, as it presents greater productivity and resistance to leafhoppers ${ }^{(7)}$.

Marandu grass (or palisade grass, its popular name) has a medium-to-high demand for soil fertility, with caespitose growth (forming robust clumps). The height can vary between 1.5 to 2.5 meters in free growth, the leaves have little hairiness, existing hairiness occurs in the sheath, racemus inflorescences with spikelets are distributed in a uniseriate way, and flowering is most intense in the months of February and March ${ }^{(8)}$. Marandu grass is not recommended for areas with constant flooding, high rain incidence, and rainfall levels associated with poorly drained soils ${ }^{(9)}$. Launched in 2003, another cultivar belonging to the $U$. brizantha species, Xaraés grass, presents greater forage and leaf accumulation compared to Marandu grass ${ }^{(10)}$. Xaraés grass is adapted to medium-fertility soils, has medium adaptation to poorly drained soils, caespitose growth, an average height of 1.5 meters in free growth, linear leaves with a glabrous blade, a sheath with light and dense hairs only on the edges, and late flowering, extending forage quality until autumn ${ }^{(8)}$.

Popularly known as "quicuio-do-amazonas," U. humidicola is considered tolerant to poorly drained soils, with high contents of aluminum and acids, and phosphorus deficiency. It has a prostrate growth, with vigorous purplish stolons, good ground-cover capacity, and can reach up to one meter in height, with flowering from December to January ${ }^{(8)}$. Another species that has been used is Urochloa ruziziensis, which has been recommended for use in no-tillage systems, mainly in crops, because it has high biomass production, easy desiccation process for straw formation, good soil cover, and limited weed development. However, this forage plant provides lower animal performance than other tropical forage $\operatorname{grasses}^{(9)}$.

The genus Megathyrsus stands out among tropical forage grasses for having high productivity and good nutritional value, with Tanzania, Mombaça, and Massai being the varieties most used(4). These forages are of great importance for national livestock production, with an estimated occupation of more than 30 million hectares of pasture ${ }^{(11)}$. However, grasses of this genus have a higher requirement for soil fertility conditions when compared to grasses of the genus Urochloa(12).

The genus Pennisetum presents caespitose growth, roots with well-defined rhizomes, erect and cylindrical stalks ranging from 3.5 to $6 \mathrm{~m}$ in height in free growth, with an inflorescence in a spiciform raceme that is classified as a panicle, although it resembles spikes $^{(13)}$. Due to their large size, they are most recommended and used for harvest and silage ${ }^{(14)}$. 


\section{Forage accumulation}

Tropical forage grasses generally have lower nutritional value than temperate grasses and legumes; however, they produce a greater amount of mass because they are more efficient in carbon fixation ( $C_{4}$ metabolism), water use, and nitrogen use ${ }^{(15)(16)}$. From 1985 to 2017, the area destined for pasture was reduced by $11 \%$, while the Brazilian cattle herd increased by $35 \%{ }^{(17)}$. With these data, we can analyze how Brazilian livestock cultivation has intensified over the years. In this context, the use of more productive forage grasses, as well as management strategies that allow them to express their production potential, plays a fundamental role in the sustainable production of Brazilian livestock, given that Brazil holds the largest commercial herd in the world, with $86 \%$ of the herd on grassland systems ${ }^{(1)}$.

In a study comparing five Urochloa cultivars, Lara et al.(10) found less annual forage accumulation for Arapoty, Basilisk, and Marandu cultivars (11, 11, and 10 tons of dry matter/ha, respectively) compared to Xaraés and Capiporã (15 and 16 tons of dry mass/ha, respectively). These last two cultivars were $32 \%$ more productive during the rainy season than the other cultivars. The authors also suggest that selecting forage grasses with a high forage accumulation rate in the most favorable climatic season can benefit the animal pasture production system by increasing the carrying capacity, utilizing harvesting, and correctly conserving the surplus for use during the least active forage-production season.

Local conditions, as well as the replacement of nutrients, are of great importance for the persistence of forage, since soil fertility is not an infinite resource. Nitrogen is directly linked to the increase in forage biomass, because it is part of the chlorophyll molecule and nucleic acids, among other vital components of the plant. However, the indiscriminate use of nitrogen fertilizer without an efficient harvest of this forage mass, whether by animals or humans, can cause damage, such as elongation of the stalk and acceleration of the senescence rate, in addition to soil acidification ${ }^{(16)}$.

Climatic variations between spring/summer (water or rainy season) and autumn/winter (dry season) result in variations in forage accumulation. Considering the annual forage dry mass accumulation of between 12 and 18 tons per hectare (Urochloa and Megathyrsus), approximately $80 \%$ of the accumulation occurs in the rainy season ${ }^{(18)(19)}$. This variation implies differences in the support capacity of pastures throughout the year. The available forage is not fully ingested by cattle (some quantity is lost to trampling, selectivity, and residue), and the percentage actually consumed represents grazing efficiency. Thus, for a daily intake of $9 \mathrm{~kg}$ of forage dry matter ( $2 \%$ of body weight per animal unit: $450 \mathrm{~kg})^{(2)}$, considering a grazing efficiency of $\pm 30 \%(3)$, approximately $30 \mathrm{~kg}$ of forage dry matter is needed per animal (Figure 1). 


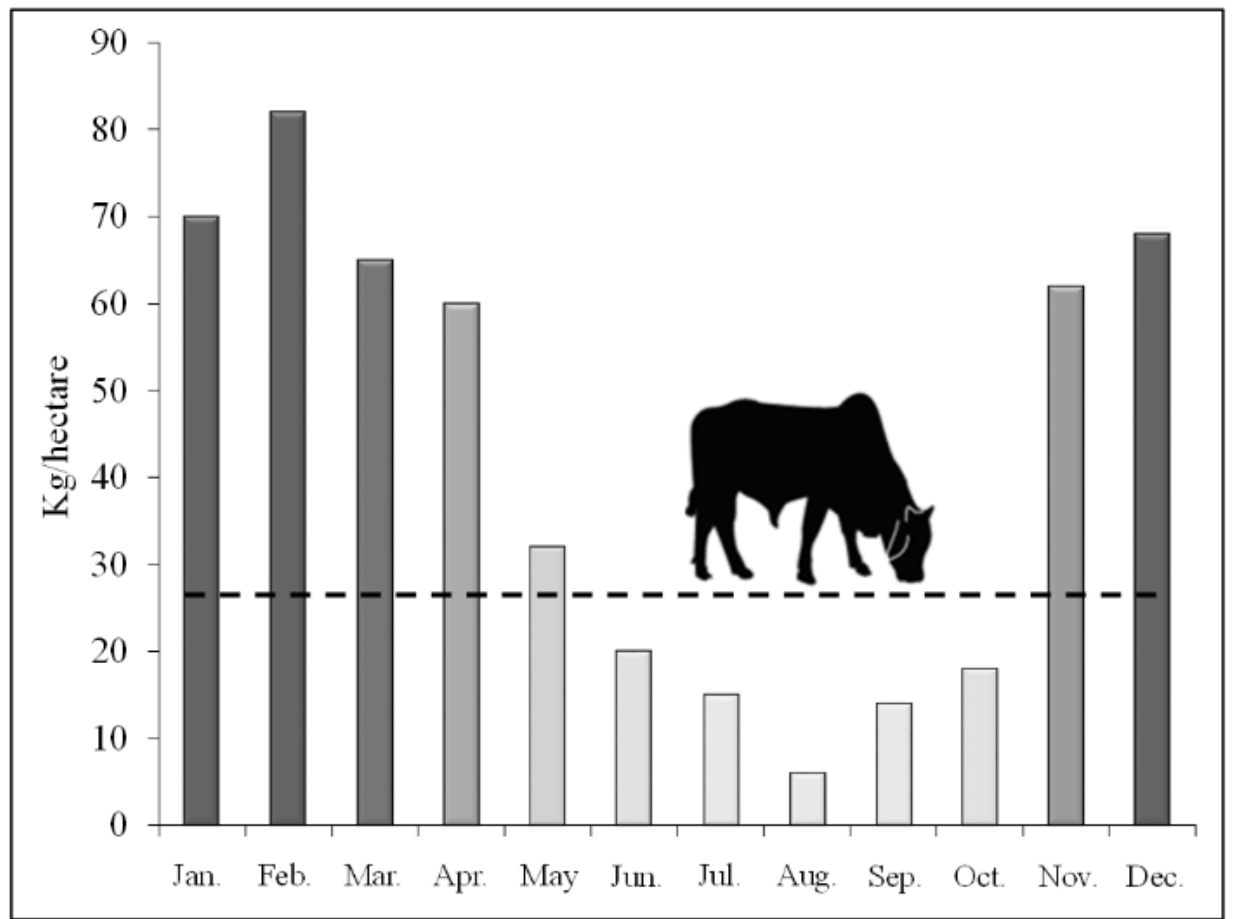

Figure 1. Daily forage accumulation as a function of the time of year and daily forage demand per animal unit (- - ), considering a grazing efficiency of 30\%. Source: Adapted from Braga et al. ${ }^{(3)}$ and Barbero et al. ${ }^{(19)}$. Image is without use restriction.

Due to the variation in forage accumulation throughout the year, the support capacity of pasture areas is greater in the rainy season, supporting a higher stocking rate $e^{(3)}$. The opposite is observed in the dry season, requiring the adoption of strategies and planning of the production system to compensate for this quantitative forage deficiency due to the demand for animals. To increase the support capacity of pastures, it is necessary to increase food supply. In this context, it is essential to explore the maximum potential for forage accumulation and grazing efficiency by the animals in order to obtain greater productivity ${ }^{(19)}$.

\section{The potential of animal production in tropical pastures}

Beef cattle production based on pasture systems is of great economic importance in Brazil. Many technologies are available to explore the potential of farms to generate increases in productivity, but it is necessary to plan investments with a view to financial viability. In a benchmarking carried out by a company in the sector ${ }^{(20)}, 206$ commercial farms were evaluated, containing more than 755,000 animals on more than 540,000 hectares of pasture. The most profitable farms were found to have better production indices than average (Table 1). The production indexes obtained in the most profitable production systems are compatible with values reported in the literature, through the adoption of some level of technologies for intensification ${ }^{(21)}$. 
Table 1. Productive indexes of beef cattle operation, observed in comparatively more profitable commercial farms.

\begin{tabular}{|c|c|c|}
\hline Productive indexes & Average & More profitable farms \\
\hline Pregnancy rate (\%) & 78 & 81 \\
\hline Gestational losses (\%) & 9 & 6 \\
\hline General mortality (\%) & 1,8 & 1,5 \\
\hline Weaning rate (\%) & 69 & 75 \\
\hline Weaned calf weight (kg) & 198 \& / 214 ఠా & 201 \& / 219 कా \\
\hline kg of Weaned calf / cow & 143 & 163 \\
\hline Stocking rate (450 kg/ha) & 1,4 & 1,8 \\
\hline Average daily gain (kg/dia) & 0.55 & 0.65 \\
\hline kg of body weight gain/ha/year & 258 & 378 \\
\hline
\end{tabular}

Source: Adapted from INTTEGRA ${ }^{(20)}$ Data were collected from 206 commercial farms, containing more than 755,000 animals on more than 540,000 hectares of pasture. Available at: https://inttegra.com/ servicos/benchmarking (accessed on June/30/2021).

Assuming adequate sanitary conditions and animal welfare, the weight gain of beef cattle given their genetic potential results from the quality of the food ingested. The necessary amount of each nutritional constituent (that is, the nutritional requirement) depends on the growth stage, genetic group, sex class, and desired performance ${ }^{(22)}$. Thus, the maximum potential for animal production in pastures is equivalent to the maximum stocking rate supported in the area without causing degradation, and is associated with meeting the nutritional requirements for the desired performance. Based on data in the literature, we can outline the goals of a beef cattle production system. Considering uncastrated male Nellore cattle, with birth weight around $30 \mathrm{~kg}$ and targeted slaughter weight of $520 \mathrm{~kg}$ at 24 months of age (early), it would be necessary to gain daily average weight from birth to slaughter around $0.68 \mathrm{~kg} / \mathrm{day}$, distributed over the climatic seasons and growth phases (Figure 2). 


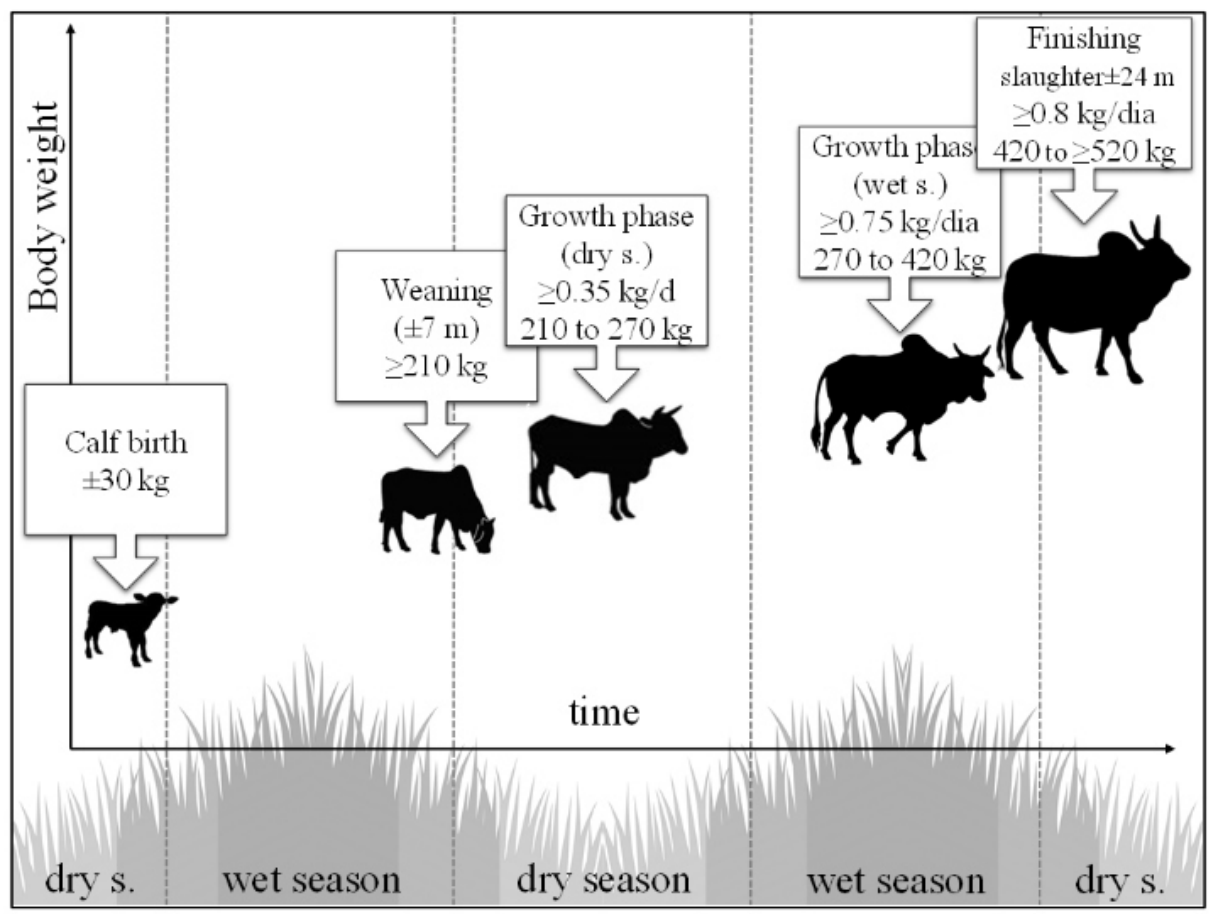

Figure 2. Illustration of targets for beef cattle production. Source: elaborated by the authors (image is without use restriction.).

\section{Forage chemical composition}

In addition to the plant species and cultivar, the chemical composition of forages can be changed by several factors, including grazing intensity ${ }^{(2)}$ and the type of system ${ }^{(23)}$, such as integration with crop and livestock, silvopastoral, intercropping with legumes ${ }^{(24)}$, nitrogen fertilization(16), weather conditions at different times of the year(25) (26), and shading(27). The chemical composition of some tropical forage grass cultivars is presented in Table 2. The productive seasonality of grasses varies with their chemical composition. Greater availability of nutrients results in high-quality forage with a low concentration of fiber in the cell wall, as well as a good relationship in the proportion of stalks to leaves ${ }^{(23)}$.

Studies have indicated improvements in the nutritive value of grasses subjected to shading and nitrogen fertilization ${ }^{(27)}$. An increase in the level of nitrogen fertilization can promote an increase in the concentration of crude protein and a proportional reduction in fibrous fractions ${ }^{(16)}$. The inclusion of legumes in grazing systems intercropped with grasses has shown improvements in the chemical composition of the diet of grazing animals, resulting in better performance ${ }^{(28)}$. System diversification, such as the introduction of legumes, tree components, or successions with different crops can result in benefits compared to forages in monoculture. Silva et al. ${ }^{(29)}$ verified that in the wet season, there was no difference between the systems for neutral detergent fiber, while the crude protein concentration was higher for the crop/livestock and 
silvopastoral integration systems (140 and $130 \mathrm{~g} / \mathrm{kg}$ of dry matter, respectively) compared to grass in monoculture (115 g/kg of dry matter).

Table 2. Compilation of values reported in the literature regarding the chemical composition of some tropical forages.

\begin{tabular}{|c|c|c|c|c|c|c|}
\hline \multirow{2}{*}{ Forage } & \multicolumn{5}{|c|}{ Chemical composition } & \multirow{2}{*}{ Source } \\
\hline & CP & NDF & ADF & Lignin & Digestibility & \\
\hline \multicolumn{7}{|l|}{ Rainy season } \\
\hline Marandu & $12-14$ & $61-62$ & $28-29$ & $\mathrm{nr}$ & $62-67$ & Silva et al. (23) \\
\hline Xaraés & $12-14$ & $58-65$ & $28-29$ & $\mathrm{nr}$ & $\mathrm{nr}$ & Barbosa et al. ${ }^{(18)}$ \\
\hline Basilisk & $10-15$ & $64-67$ & $32-33$ & $05-06$ & 61 & Lopes et al. ${ }^{(27)}$ \\
\hline Tanzânia & $10-12$ & $76-78$ & $71-44$ & $\mathrm{nr}$ & $\mathrm{nr}$ & Barbero et al. ${ }^{(19)}$ \\
\hline Mombaça & $10-13$ & $75-76$ & $\mathrm{nr}$ & $02-03$ & $59-63$ & Euclides et al. ${ }^{(25)}$ \\
\hline \multicolumn{7}{|l|}{ Dry season } \\
\hline Marandu & 05-08 & $70-79$ & $\mathrm{nr}$ & 03-05 & $43-53$ & Euclides et al.(26) \\
\hline Xaraés & $06-08$ & $66-69$ & $32-33$ & $\mathrm{nr}$ & $\mathrm{nr}$ & Barbosa et al.(18) \\
\hline Xaraés & 04-08 & $70-80$ & $\mathrm{nr}$ & 04-05 & $41-49$ & Euclides et al.(25) \\
\hline Tanzânia & 07-09 & $77-80$ & $45-47$ & $\mathrm{nr}$ & $\mathrm{nr}$ & Barbero et al.(19) \\
\hline Mombaça & $08-10$ & $73-76$ & $\mathrm{nr}$ & 02-05 & $52-58$ & Euclides et al. ${ }^{(25)}$ \\
\hline
\end{tabular}

Crude protein (CP), neutral detergent fiber (NDF), acid detergent fiber (ADF), and not reported (NR). Results from the literature, in which samples were taken from green leaves by hand-plucking.

Climate variations throughout the year affect forage characteristics, as well as the growth curve of cattle, and so different rates of weight gain must be considered from birth to slaughter. After defining the production goals, it is necessary to assess whether the chemical composition of the forage, once available supply is compatible with high dry-matter consumption, meets the nutritional requirements for the desired performance (Table 3).

When the chemical composition of the forage is incompatible with the nutritional requirement for the targeted weight gain, it is necessary to evaluate the adoption of strategies to achieve this goal. It is worth noting that, as already discussed, tropical forage plants present variations in chemical composition depending on the species, cultivar, climatic season, and management. Well-managed pastures have good chemical composition and can provide intake of nutritional constituents compatible with the requirement for weight gain above $1.0 \mathrm{~kg} / \mathrm{animal} / \mathrm{day}^{(2)(16)}$. There are additional factors and technologies capable of increasing productivity rates, as discussed below. 
Table 3. Chemical composition of forage and percentage of nutritional requirement of beef cattle as a function of the year's climatic seasons and targeted performance.

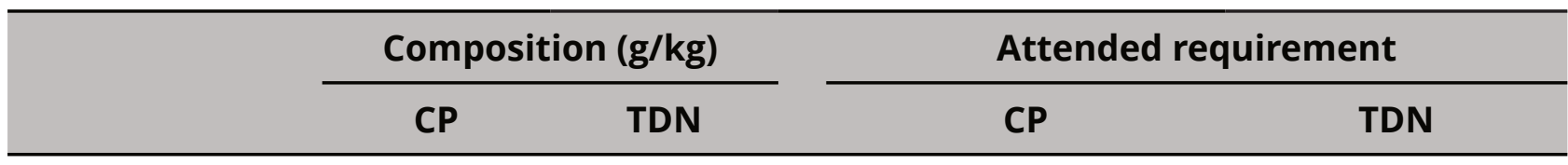

Growing phase (dry season), B. Indicus, young bulls, 210 to $270 \mathrm{~kg}$, weight gain: $0.35 \mathrm{~kg} / \mathrm{d}$

\begin{tabular}{|c|c|c|c|c|}
\hline Marandu grass & 0.08 & 0.52 & $83 \%$ & $96 \%$ \\
\hline Mombaça grass & 0.09 & 0.53 & $76 \%$ & $86 \%$ \\
\hline \multicolumn{5}{|c|}{ Growing phase (wet season), B. Indicus, young bulls, 270 to $420 \mathrm{~kg}$, weight gain: $0.75 \mathrm{~kg} / \mathrm{d}$} \\
\hline Marandu grass & 0.14 & 0.55 & $125 \%$ & $93 \%$ \\
\hline Mombaça grass & 0.12 & 0.56 & $108 \%$ & $94 \%$ \\
\hline
\end{tabular}

Finishing phase (dry season), B. Indicus, young bulls, 420 to $520 \mathrm{~kg}$, weight gain: $0.8 \mathrm{~kg} / \mathrm{d}$

\begin{tabular}{ccccc}
\hline Marandu grass & 0.08 & 0.52 & $85 \%$ & $91 \%$ \\
Mombaça grass & 0.09 & 0.53 & $96 \%$ & $92 \%$ \\
\hline
\end{tabular}

Crude protein (CP) and total digestible nutrients (TDN) Source: Based on the chemical composition of forage, intake, and nutritional requirements of cattle reported in the literature by Barbero et al.(19), Barbero et al. (2), and Valadares Filho et al.(22).

\section{Increase in productivity índices}

\section{Soil amendment and fertilization}

According to Hodgson ${ }^{(30)}$, the animal production process in pastures can be divided into three stages: forage growth or production, use or intake of the forage produced, and conversion or transformation of the consumed forage into an animal product. The intensification of animal production in pastures depends on the efficiency of the three stages of the process. The use of agricultural correctives and fertilizers is essential in the search for increased forage production, followed by the adoption of other tools for intensification, such as grazing, supplementation, or others. Each tool affects more than one step, and interacts with other interventions during the production process.

The use of correctives and fertilizers is normally the first tool used in the intensification of animal production systems in pastures, and there are a number of essential nutrients for the growth and development of forage plants, including macronutrients $(\mathrm{N}, \mathrm{P}, \mathrm{K}, \mathrm{Ca}, \mathrm{Mg}$, and $\mathrm{S})$ and micronutrients $(\mathrm{Cu}, \mathrm{Fe}, \mathrm{Zn}, \mathrm{Mn}, \mathrm{B}, \mathrm{Cl}, \mathrm{Ni}, \mathrm{Mo} \text {, and } \mathrm{Co})^{\left({ }^{(13)}\right.}$. There is no nutrient that is more important than the others for plant growth, only nutrients needed in greater or lesser amounts. On the other hand, in the Cerrado ecosystem, where Brazilian beef cattle are predominant, the soils usually have low $\mathrm{pH}$, high aluminum content, low base saturation, and low calcium, magnesium, and available phosphorus. These characteristics limit the development of forage plants, especially when aiming for high animal production. Under these conditions, it is important to carry out soil sampling and analysis, identify deficiencies, and meet the basic nutrient 
needs of plants through soil correction and fertilization practices ${ }^{(13)}$.

After correcting the main deficiencies in soil nutrients, nitrogen availability largely determines the forage accumulation rate, so that responses to nitrogen fertilization are expressed in terms of forage production. This occurs because leaf nitrogen is associated with photosynthetic enzymes, assimilation of $\mathrm{CO}_{2}$ by the plant, and accumulation of biomass(31).

Results observed in the literature indicate increases in available forage mass or forage production with nitrogen fertilization in the rainy season. Bernardi et al. ${ }^{(32)}$ carried out a meta-analytic study compiling data published in the literature and found linear responses for forage accumulation of grasses of the genera Urochloa and Megathyrsus at doses of up to $700 \mathrm{~kg}$ of nitrogen per hectare. For Megathyrsus maximus cv. Tanzania managed under continuous stocking and maintained at a height of $60 \mathrm{~cm}$, Canto et al. ${ }^{(33)}$ observed a linear increase in forage mass and stocking rate at doses of up to $400 \mathrm{~kg}$ of nitrogen per hectare. However, the weight gain per animal was similar between the doses tested, with a daily average of $0.73 \mathrm{~kg}$ per animal. Nitrogen fertilization linearly increased animal production per unit area, with values of $420,600,750$, and $930 \mathrm{~kg} / \mathrm{ha}$ when applied at 100, 200,300, or $400 \mathrm{~kg}$ of nitrogen per hectare, respectively.

Delevatti et al.(16) evaluated the effect of applying 0,90, 180, or $270 \mathrm{~kg}$ of nitrogen per hectare when pastures of Urochloa brizantha cv. Marandu were maintained at a height of $25 \mathrm{~cm}$ under continuous stocking. The authors observed linear increases in the daily rate of forage accumulation (from \pm 30 to $>80 \mathrm{~kg}$ of forage dry matter per hectare) as the applied nitrogen dose increased. Such an increase in forage accumulation resulted in a linear increase in stocking rate to maintain the 25-cm-high forage canopy. The authors reported a linear increase in animal production as a function of the nitrogen dose (Table 4).

Table 4. Effect of nitrogen fertilization rate of pastures on stocking rate and productivity in beef cattle production during the rainy season.

\begin{tabular}{|c|c|c|c|c|c|}
\hline \multirow[t]{2}{*}{ Parameters } & \multicolumn{4}{|c|}{$\begin{array}{c}\text { Nitrogen fertilization } \\
\text { Nitrogen dosis (kg/ha/year) }^{1}\end{array}$} & \multirow[t]{2}{*}{ Source } \\
\hline & 0 & 90 & 180 & 270 & \\
\hline Stocking rate (450 kg/ha) & 3.4 & 4.6 & 5.8 & 6.5 & \multirow{2}{*}{ Delevatti et al. ${ }^{(16)}$} \\
\hline $\begin{array}{l}\text { Productivity (kg body } \\
\text { weight/ha) }\end{array}$ & 510 & 780 & 840 & 960 & \\
\hline \multicolumn{6}{|c|}{ Nitrogen dosis (kg/ha/year) ${ }^{2}$} \\
\hline & 100 & 200 & 300 & 400 & \multirow{3}{*}{ Canto et al. ${ }^{(33)}$} \\
\hline Stocking rate (450 kg/ha) & 3.2 & 4.5 & 5.8 & 7.1 & \\
\hline $\begin{array}{l}\text { Productivity (kg body } \\
\text { weight/ha) }\end{array}$ & 420 & 600 & 750 & 930 & \\
\hline
\end{tabular}

Stocking rate: animal unit ( $450 \mathrm{~kg}$ body weight) per hectare. Productivity: $\mathrm{kg}$ of body weight gain per hectare. 1 Urochloa brizantha cv. Marandu under continuous stocking, average daily weight gain $\pm 0.92 \mathrm{~kg} / \mathrm{day}$, soils corrected for $\mathrm{V} \% \geq 45,180 \mathrm{~kg} / \mathrm{h}$ a of 4-14-8 fertilizer (urea, $\mathrm{P}_{2} \mathrm{O}_{5}$, and $\mathrm{K} O$ ).

2 Megathyrsus maximus cv. Tanzania under continuous stocking, average daily weight gain $\pm 0.73 \mathrm{~kg} / \mathrm{day}$, soils fertilized with $120 \mathrm{~kg} /$ hectare of $\mathrm{P}_{2} \mathrm{O}_{5}$. 


\section{Pasture management}

Grazing management can influence forage accumulation, grazing efficiency, and forage conversion. Grazing frequency determines the tiller defoliation point on the forage growth curve, and grazing intensity determines the proportion of harvested forage and residue. The forage canopy height corresponding to $95 \%$ interception of incident light has been shown to be a satisfactory tool for guiding grazing management for a wide range of morphological types, allowing for greater forage production with a high proportion of leaves and a low proportion of dead material(34). This parameter tends to direct the management of forage canopy height. Reviewing data from the literature, Euclides et al. (35) indicated recommendations for forage canopy height at entry between 70 and $90 \mathrm{~cm}$ and exit height between 30 and $50 \mathrm{~cm}$ for some forages of the Megathyrsus genus (Mombaça and Tanzania). According to the same authors, for some forages of the Urochloa genus (Marandu and Xaraés), the entry height should be approximately 25 to $30 \mathrm{~cm}$, and the exit height should be between 15 and $20 \mathrm{~cm}$. However, the differences between species and cultivars must be considered.

\section{Grazing intensity}

According to the production model proposed by Mott ${ }^{(36)}$, the higher the stocking rate, the greater the grazing pressure, resulting in a lower forage canopy height. This would imply a reduction in the supply of forage and a consequent decrease in animal performance. On the other hand, the lower the stocking rate, the lower the grazing pressure and the greater the forage supply. This results in a high supply of forage and high individual weight gain, although this requires a low stocking rate and lower productivity per area. The challenge is to adjust the optimal grazing point, reconciling individual weight gain and productivity per area (Figure 3).

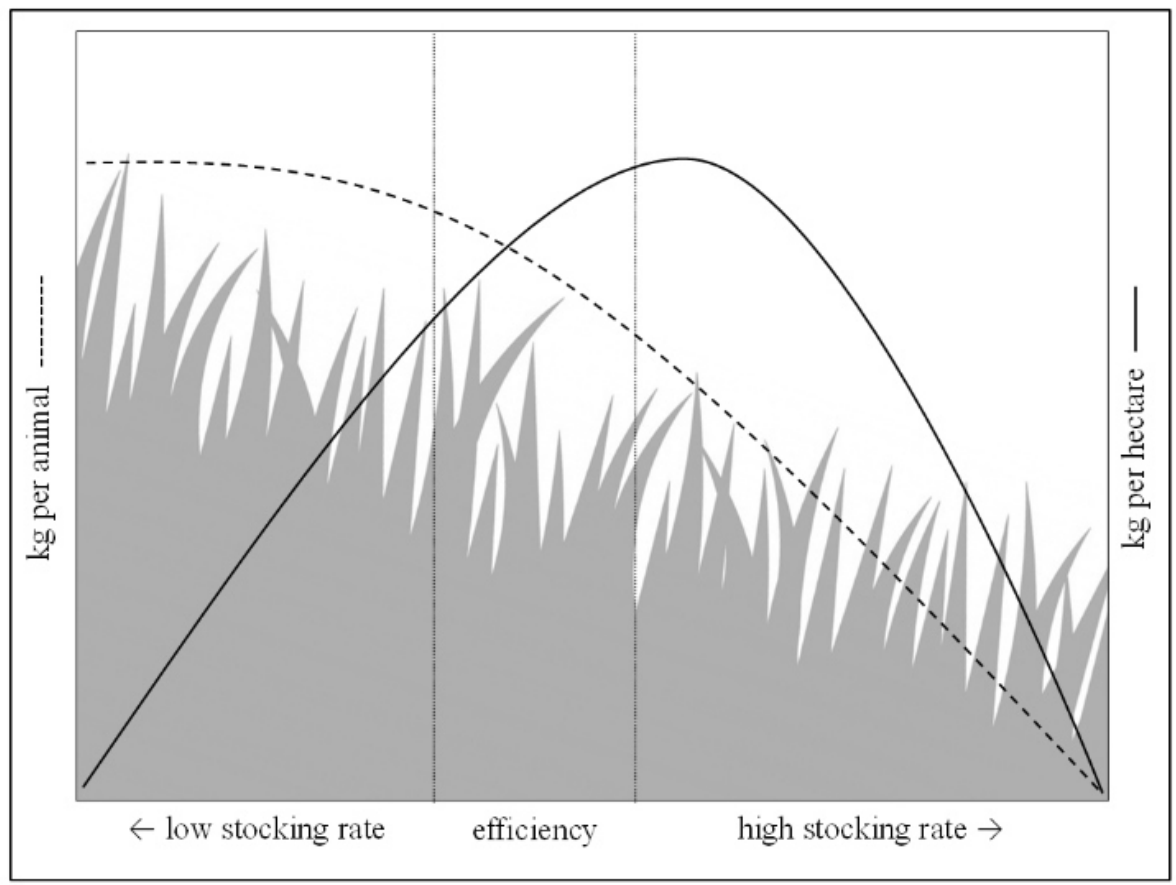

Figure 3. Beef cattle weight gain and productivity per area as a function of stocking rate. Source: elaborated by the authors (adapted from $\operatorname{Mott}^{(36)}$ ). 
Barbero et al. (19) evaluated Tanzania grass pastures under continuous stocking and observed a linear increase in forage mass as the canopy height increased $(20,40,60$, or $80 \mathrm{~cm}$ ). However, the crude protein concentration decreased, while the fibrous fractions linearly increased with an increase in forage canopy height. According to the authors, the stocking rate also linearly decreased to maintain higher sward heights, but the daily weight gain of male Nellore cattle linearly increased as a function of canopy height. Thus, the authors suggested that the equilibrium point between the average daily gain and production per hectare was around 40 to $60 \mathrm{~cm}$, with daily weight gain per animal around $1.0 \mathrm{~kg}$ and average productivity above $500 \mathrm{~kg}$ of body weight (equivalent to more than $250 \mathrm{~kg}$ of carcass) per hectare, though this was true only during the rainy season (Table 5).

Table 5. Beef cattle productivity in pastures managed under continuous stocking during the rainy season under different grazing intensities.

\begin{tabular}{|c|c|c|c|c|c|c|}
\hline \multirow{2}{*}{ Forage } & \multirow{2}{*}{$\begin{array}{c}\begin{array}{c}\text { Grazing } \\
\text { height }\end{array} \\
\mathrm{cm}\end{array}$} & \multirow{2}{*}{$\begin{array}{c}\begin{array}{c}\text { Stocking } \\
\text { rate }\end{array} \\
\text { AU/ha }\end{array}$} & \multirow{2}{*}{$\begin{array}{c}\begin{array}{c}\text { Average } \\
\text { daily gain }\end{array} \\
\mathrm{kg} / \mathrm{d}\end{array}$} & \multicolumn{2}{|c|}{ Productivity } & \multirow{2}{*}{ Source } \\
\hline & & & & kg/ha/d ${ }^{1}$ & kg/ha² & \\
\hline \multirow{4}{*}{ Tanzania } & 20 & 6.5 & 0.745 & 4.8 & 873 & \multirow{4}{*}{ Barbero et al. ${ }^{(19)}$} \\
\hline & 40 & 5.2 & 0.988 & 5.1 & 927 & \\
\hline & 60 & 3.9 & 1.053 & 4.1 & 741 & \\
\hline & 80 & 2.6 & 1.193 & 3.1 & 561 & \\
\hline \multirow{4}{*}{ Marandu } & 10 & 6.8 & 0.190 & 1.3 & 234 & \multirow{4}{*}{ Da Silva et al. ${ }^{(23)}$} \\
\hline & 20 & 5.0 & 0.510 & 2.6 & 459 & \\
\hline & 30 & 3.8 & 0.750 & 2.8 & 507 & \\
\hline & 40 & 2.2 & 0.930 & 2.0 & 369 & \\
\hline
\end{tabular}

Animal unit (AU $=450 \mathrm{~kg}$ of body weight).

1 Daily productivity (kg of body weight) calculated using data obtained from the articles.

2 Productivity in the rainy season, calculated considering 180 days.

Carloto et al.(37) observed similar results for $U$. brizantha cv. Xaraés managed in continuous stocking at 15,30 , or $45 \mathrm{~cm}$ height during the wet season, during which time forage mass increased with pasture height. However, crude protein concentration and in vitro organic matter digestibility decreased at the same time. Dry matter intake was lower in pastures managed at $15 \mathrm{~cm}$ (1.89\% of body weight) than in pastures managed at $30 \mathrm{~cm}$ ( $2.26 \%$ of body weight) and $45 \mathrm{~cm}$ (2.34\% of body weight), but the average daily weight gain was not different between pasture heights ( $\pm 0.7 \mathrm{~kg}$ per steer). Stocking rate decreased with increasing pasture height, but the gain per area was greater at $15 \mathrm{~cm}$ (678 kg/ha) than at $45 \mathrm{~cm}(324 \mathrm{~kg} / \mathrm{ha})$. 
Regarding the effect of pasture height on the forage nutritional value, consumption, and weight gain of animals, these results suggest that a greater mass of forage offered, resulting from the management criterion established with the highest pasture heights, provides an increase in the consumption of forage dry matter, and consequently, of the components of nutritional interest. The higher forage consumption in pastures with greater height seems to compensate for the better nutritive value observed at lower heights of the forage canopy.

Although the literature is consistent in terms of increasing productivity as the stocking rate increases and pasture height decreases, livestock systems that exploit high grazing intensities can adversely affect the slaughter age of the herd, resulting in a longer time for remuneration of invested capital and in the slaughter of late animals with inferior quality meat compared to animals slaughtered early. Another factor to be considered is the possibility of area degradation when low pasture heights are used. Thus, the maintenance of pasture at intermediate heights can be recommended, seeking a balance between average daily gain and production per hectare.

\section{Forage stockpiling}

The main factor limiting the production of cattle on pasture is the lack of forage during the dry period. Regardless of fertilization, non-irrigated tropical grasses generally have higher forage accumulation rates during the summer, intermediate rates in autumn and spring, and very low rates in winter. As the food requirement per animal unit is practically constant, there is an imbalance between production and demand for forage by the herd throughout the year ${ }^{(38)}$.

Several alternatives can be used to balance the seasonality of forage production, including pasture deferrals. This technique consists of the deferral (exclusion of grazing) of a part of the pasture area at the end of the rainy season, with the purpose of accumulating forage in the field, to be used during the dry season. This strategy has proved to be a viable alternative, as it is considered to be of low cost and easy to adopt. This management style also allows for the natural reseeding of fields and the accumulation of organic matter in the soil, which can invigorate degraded pastures. However, loss of nutritive value and forage quality can occur, especially when there is excessive elongation of stalks. This means that this type of management is indicated only for forage plants that present low accumulation of stalks and a good proportion of leaves, resulting in smaller reductions in the nutritive value, highlighting most of the grasses of the genus Urochloa ${ }^{(39)}$.

Teixeira et al.(38) evaluated the production of Urochloa decumbens pastures under grazing, deferred for periods of 95 and 140 days, associated with four nitrogen fertilization strategies at the beginning and end of summer ( 0 and 0; 100 and 0; 50 and 50; 0 and $100 \mathrm{~kg} / \mathrm{ha}$, respectively). The authors observed that the daily production of dry matter, when compared to summer, was reduced by $8 \%, 89 \%$, and $58 \%$ in the autumn, winter, and spring seasons, respectively. The strategy of applying nitrogen in early summer provides the greatest total forage production during the year. However, nitrogen-fertilized pastures in late summer promote greater forage accumulation during the deferment, and nitrogen application strategies in late summer and splitting 
in early and late summer increase forage production and crude protein content, in addition to reducing fibrous fractions for pastures deferred for 95 and 140 days. The authors recommend this strategy for pastures deferred for 95 or 140 days, as it helps to reduce the seasonality of forage production during the year. Nitrogen fertilization reduces the period of pasture deferment without reducing forage production.

\section{Supplementation}

The conversion of forage into animal products is largely determined by the consumption and nutritional value of the forage. Thus, grazing management plays a role in nutrient consumption, as discussed above. However, tropical pastures are rarely able to supply all the nutrients needed to meet the nutritional requirements for high performance ${ }^{(40)}$. In this context, the use of concentrated supplements in a grazing system can provide an increase in animal performance, combined with increases in stocking rate, thus allowing for an increase in the productivity of the system.

\section{Supplementation during the rainy season}

During the rainy season, due to a set of factors that favor the development of forage plants, pastures have the best nutritional value ${ }^{(41)}$. Intensively managed tropical forages, fertilized with nitrogen and grazed with adequate frequency and intensity, have a high protein content, reaching up to $16 \%^{(16)}$. Thus, the high degradability of forage protein in the rainy season can promote a lack of synchrony between nitrogen and energy in the rumen, and disfavor microbial protein synthesis, causing excessive losses of nitrogen compounds ${ }^{(40)}$. In this context, the provision of energetic supplements that are readily available in the rumen would optimize the microbial assimilation of nitrogen. As previously shown, pastures with higher grazing intensities have greater gain per unit area due to the high stocking rate, but with lower animal performance due to the low forage intake, due to the low forage supply. However, with the addition of supplements, it may be possible to obtain incremental weight gain, even by exploiting high stocking rates.

Barbero et al.(2) evaluated the heights $(15,25$, and $35 \mathrm{~cm})$ of Urochloa brizantha $\mathrm{cv}$. Marandu under continuous stocking grazed by young Nellore bulls receiving $3 \mathrm{~g} / \mathrm{kg}$ body weight supplement. In a second experiment, the same authors combined decreasing doses $(6,3$, or $0 \mathrm{~g} / \mathrm{kg}$ body weight) of supplements associated with increasing sward heights $(15,25$, or $35 \mathrm{~cm})$. The authors observed that weight gain linearly increased due to the increase in forage mass; however, the gain per area linearly decreased with increasing pasture height. In the second experiment, the average daily weight gain was not altered by feeding strategies $(1.1 \mathrm{~kg} /$ animal). These results indicate that the combination of high grazing intensity with supplementation may be the key to achieving maximum production per unit area associated with maximum animal performance in pastures during the wet season (Table 6). 
Table 6. Average daily gain by young bulls as a function of pasture grazing height of the genus Urochloa (syn. Brachiaria) and supplementation during the rainy season.

\begin{tabular}{|c|c|c|c|}
\hline \multirow{2}{*}{$\begin{array}{c}\text { Grazing } \\
\text { height }(\mathrm{cm})\end{array}$} & \multicolumn{2}{|c|}{ Average daily gain $(\mathrm{kg} / \mathrm{d})$} & \multirow{2}{*}{$\begin{array}{l}\text { Difference } \\
(\mathrm{kg} / \mathrm{d})\end{array}$} \\
\hline & Without supplement & With supplement ${ }^{1}$ & \\
\hline 15 & 0.50 & 1.08 & 0.58 \\
\hline 25 & 0.91 & 1.15 & 0.24 \\
\hline 35 & 1.13 & 1.20 & 0.07 \\
\hline
\end{tabular}

${ }_{1}$ Supply of $3 \mathrm{~g}$ supplement/kg body weight (16\% crude protein and $66 \%$ total digestible nutrients).

${ }^{2}$ Difference in performance with or without supplement. Source: adapted from Barbero et al. ${ }^{(2)}$.

Supplementation during the dry season

In the dry season, cattle feed mainly on stockpiled pastures that have low nutritional value, characterized by a high proportion of fibrous fractions and low protein content ${ }^{(40)}$. According to the authors, even if potentially digestible fiber is available in dry pastures, protein is the nutrient that limits animal performance. In this situation, the purpose of supplementation is to adjust deficient nitrogen levels in the forage in such a way as to increase the efficiency of degradation of the fibrous fraction and, consequently, the passage rate and forage intake ${ }^{(42)(43)}$. Under the conditions described, in which the exclusive forage diet in the dry period can cause weight loss, maintenance, or poor performance, supplementation is essential ${ }^{(44)}$ (Table 7).

Table 7. Effect of supplementation on the performance of rearing cattle during the dry season on pastures receiving different types of supplement.

\begin{tabular}{|c|c|c|}
\hline \multicolumn{2}{|c|}{ Supplement } & \multirow{2}{*}{$\begin{array}{l}\text { Average daily } \\
\text { gain (kg/d) }\end{array}$} \\
\hline Description & Supplied amount & \\
\hline Mineral mixed ${ }^{1}$ & \pm 0.06 kg/day & - 0.1 kg/day \\
\hline Mineral mixed + urea ${ }^{1}$ & $\pm 0.5 \mathrm{~g} / \mathrm{kg}$ of body weight & 0.2 kg/day \\
\hline Min. + proteic + urea ${ }^{1}$ & $\pm 1 \mathrm{~g} / \mathrm{kg}$ of body weight & 0.35 kg/day \\
\hline Multiple $^{2}$ & $\pm 3 \mathrm{~g} / \mathrm{kg}$ of body weight & 0.6 kg/day \\
\hline
\end{tabular}

${ }^{1}$ Growth phase grazing Urochloa decumbens pastures. Source: Zanetti et al.(42);

${ }^{2}$ Growgh phase grazing Urochloa brizantha pastures Multiple supplements (mineral, protein, and energy: $18 \%$ crude protein and $75 \%$ total digestible nutrients). Source: Paulino et al. ${ }^{(44)}$ 
The formulation of supplements and the amount of supplement provided are defined as a function of the forage characteristics in relation to the nutritional requirement for the desired weight gain. In this context, the formulation can be carried out simply to ensure the maintenance of weight of cows and bulls; to provide moderate gains of 0.2 to $0.3 \mathrm{~kg} /$ day for growing animals; gains of 0.5 to $0.6 \mathrm{~kg} /$ day when the aim is to prepare heifers for the first breeding season at 14 months or finishing and slaughter of bulls at 24 months of age; or obtaining a gain above $0.6 \mathrm{~kg}$ /day for finishing animals during the dry season ${ }^{(4)}$ (46) (47) (48) (Table 8).

Tabela 8. Performance of beef cattle receiving supplements during the finishing phase in the dry season.

\begin{tabular}{|c|c|c|c|c|c|c|c|}
\hline \multirow{2}{*}{ Forage } & \multirow{2}{*}{ Animals } & \multirow{2}{*}{ Suppl. } & \multirow{2}{*}{$\begin{array}{l}\text { Stocking } \\
\text { rate }\end{array}$} & \multicolumn{3}{|c|}{$\begin{array}{r}\text { Body weight and performance } \\
\text { (kg) }\end{array}$} & \multirow{2}{*}{ Source } \\
\hline & & & & Initial & Final & kg/dia & \\
\hline Marandu & $\mathrm{C}+\mathrm{F}$ & $1 \%$ & 2.0 & 266 & 332 & 0.78 & Barbero et al. ${ }^{(43)}$ \\
\hline Marandu & $\mathrm{Z}+\mathrm{NC}$ & $1 \%$ & 3.2 & 431 & 518 & 0.82 & Barbero et al.(45) \\
\hline Marandu & $\mathrm{C}+\mathrm{NC}$ & $0.5 \%$ & 1.7 & 391 & 502 & 0.73 & Sampaio et al.(46) \\
\hline Mombaça & $\mathrm{Z}+\mathrm{CM}$ & $0.4 \%$ & 5.2 & 300 & 351 & 0.61 & Branco et al..$^{(47)}$ \\
\hline Mombaça & $\mathrm{Z}+\mathrm{NC}$ & $1.8 \%$ & 2.1 & 366 & 527 & 1.25 & Bento(48) \\
\hline
\end{tabular}

Genetic group: Zebu (Z: Bos indicus), European (E: Bos taurus), or crossbreed (C). Sex class: non-castrated male (NC), castrated male (CM), or female (F). Suppl: amount of supplement used in relation to percentage of body weight (\%). Stocking rate: animal unit (450 kg of body weight)/ha.

Thus, a wide range of possibilities exist regarding the amounts and formulations of supplements with different nutritional characteristics. Minerals mixed with urea, protein supplement (with the addition of true protein sources), and multiple supplements (mineral, protein, and energy) can be used to meet the requirements of specific categories according to desired weight gain levels ${ }^{(40)}$.

\section{Final considerations}

Considering the presented productivity indexes, we can infer that well-managed tropical pastures, with corrected soil chemical attributes and fertilization, balanced supplementation, high stocking rate, and satisfactory weight gain, can generate a productivity of approximately $900 \mathrm{~kg}$ of body weight/hectare during the rainy season. During the dry season, the use of stockpiled forage and supplementation for growing and finishing animals provides approximately $360 \mathrm{~kg}$ of body weight per hectare. Thus, 
we could have an annual production potential of tropical pastures of approximately $1260 \mathrm{~kg}$ of body weight (approximately $630 \mathrm{~kg}$ of carcass) per hectare.

In general, tropical forages have high productive potential and good nutritional value, and these characteristics are mainly controlled by environmental conditions. Thus, the proper management of forage becomes a key factor in providing a high stocking rate, with good individual weight gain, high productivity, and lack of productive decline in pastures. Under these conditions, we can infer that when technologies are adopted to increase productivity, the production of beef cattle in tropical pastures has a high response potential.

\section{Conflict of interest}

The authors declare no conflict of interest.

\section{Acknowledgement}

The authors would like to thank the Coordination for the Improvement of Higher Education Personnel (CAPES: funding code \#001) and the National Council for Scientific and Technological Development (CNPq: \#302998/2020-9). The authors would also like to thank Dr. João Restle for his valuable contributions in the preparation of this material.

\section{References}

1. Associação Brasileira das Indústrias Exportadoras de Carnes - ABIEC. Perfil da Pecuária no Brasil. São Paulo, 2020. Disponível em: http://abiec.com.br/publicacoes/beef-report-2020/. Acesso em: 3 jun. 2021.

2. Barbero RP, Malheiros EB, Araújo TLR, Nave RLG, Mulliniks JT, Berchielli TT, Ruggieri AC, Reis RA. Combining Marandu grass grazing height and supplementation level to optimize growth and productivity of yearling bulls. Animal Feed Science and Technology. 2015;209:110-118. https://doi.org/10.1016/ j.anifeedsci.2015.09.010

3. Braga GJ, Pedreira CGS, Herling VR, Luz PHDC. Eficiência de pastejo de capim-marandu submetido a diferentes ofertas de forragem. Pesquisa Agropecuária Brasileira. 2007; 42:1641-1649. https://doi.org/ 10.1590/S0100-204X2007001100017

4. Jank L, Barrios SC, Valle CB, Simeao RM, Alves GF. The value of improved pastures to Brazilian beef production. Crop and Pasture Science. 2014;65(11):1132-1137. https://doi.org/10.1071/CP13319

5. Pedreira CGS, Silva VJ, Pedreira BC, Sollenberger LE. Herbage accumulation and organic reserves of palisade grass in response to grazing management based on canopy targets. Crop Science. 2017;57(4):2283-2293. https://doi.org/10.2135/cropsci2016.11.0957

6. Boddey RM, Casagrande DR, Homem BG, Alves BJ. Forage legumes in grass pastures in tropical Brazil and likely impacts on greenhouse gas emissions: A review. Grass and Forage Science. 2020;75(4):357-371. https://doi.org/10.1111/gfs.12498 
Production potential of beef cattle in tropical pastures: a review

Barbero R P et al.

7. Nunes SG, Boock A, Penteado MI de O, Gomes DT. Brachiaria brizantha cv. Marandu. Documentos Embrapa, 21. Embrapa/CNPGC, Campo Grande, MS, Brazil, 1984.

8. Fonseca DM, Martuscello JM (eds). Plantas Forrageiras. Viçosa: Editora UFV. 2010: 537.

9. Mass Jr R, Domiciano LF, Ribeiro LFC, Pedreira BC. Growth responses of nine tropical grasses under flooding conditions. Tropical Grasslands - Forrajes Tropicales. 2016;4(1):1-7. https://doi.org/10.17138/ TGFT(4)1-7

10. Lara, MA, Silva VJ, Sollenberger LE, Pedreira CG. Seasonal herbage accumulation and canopy characteristics of novel and standard brachiariagrasses under $\mathrm{N}$ fertilization and irrigation in southeastern Brazil. Crop Science. 2020;61(2):1468-1477. https://doi.org/10.1002/csc2.20353

11. Borges do Valle, Cacilda, Jank, Liana, Simeão Resende, Rosangela Maria, O melhoramento de forrageiras tropicais no Brasil. Revista Ceres [Internet]. 2009; 56 (4): 460-472. https://www.redalyc.org/ articulo.oa?id=305226808013

12. Werner JC, Paulino VT, Cantarella H, Andrade NO, Quaggio JA. Forrageiras. In: Raij, B. van; Cantarella, H.; Quaggio, J.A.; Furlani, A.M.C. Recomendações de adubação e calagem para o Estado de São Paulo. 2nd ed. Campinas: Instituto Agronômico de Campinas, Fundação IAC. 1996;263-273.

13. Reis RA, Bernardes TF, Siqueira GR (eds). Forragicultura - Ciência, tecnologia e gestão dos recursos forrageiros. Jaboticabal: Editora FUNEP. 2014; 714 p.

14. Araújo JAS, Almeida JCC, Reis RA, Carvalho CAB, Barbero RP. Harvest period and baking industry residue inclusion on production efficiency and chemical composition of tropical grass silage. Journal of Cleaner Prodrodution. 2020;266:121953. https://doi.org/10.1016/j.jclepro.2020.121953

15. Sollenberger LE, Vendramini JM, Pedreira CG, Rios EF. Warm-Season Grasses for Humid Areas. In: Moore KJ, Collins M, Nelson JC, Redfearn DD. Forages: The Science of Grassland Agriculture, 2 (7th ed). 2020:331-345. Disponível em: https://doi.org/10.1002/9781119436669.ch18

16. Delevatti LM, Cardoso AS, Barbero RP, Leite RG, Romanzini EP, Ruggieri AC, Reis RA. Effect of nitrogen application rate on yield, forage quality, and animal performance in a tropical pasture. Scientific reports. 2019;9(1):7596. https://doi.org/10.1038/s41598-019-44138-x

17. Instituto Brasileiro de Geografia e Estatística - IBGE. Disponível em: https://www.ibge.gov.br/. Acesso em: 1 jun. 2021.

18. Castro LM, Barbosa MAAF, Barbero RP, Brito VC, Saad RM, Ribeiro ELA, Mizubuti IY, Bridi AM. Produção de forragem e composição estrutural de pastos de Brachiaria brizantha cv. Xaraés manejados em diferentes alturas de pastejo. Semina Ciências Agrárias (Online). 2013,34(6):4145-4156. https://www.redalyc.org/articulo.oa?id=445744138035

19. Barbero RP, Barbosa MAAF, Castro LM, Ribeiro ELA, Mizubuti IY, Bumbieris Júnior VH, Silva LDF, Massaro Júnior FL. Desempenho de novilhos de corte em pastos de capim-tanzânia sob quatro alturas 
Production potential of beef cattle in tropical pastures: a review Barbero R P et al.

de desfolha. Arquivo Brasileiro de Medicina Veterinária e Zootecnia. 2014;66(2):481-488. https://doi.org/ 10.1590/1678-41625481

20. Instituto de Métricas Agropecuárias - INTTEGRA. Disponível em: https://inttegra.com/servicos/ benchmarking. Acesso em: 30 jun. 2021.

21. Jaurena M, Durante M, Devincenzi T, Savian JV, Bendersky B, Moojen FG, Pereira M, Soca P, Quadros FLF, PizZio R, Nabinger C, Carvalho PCF, Lattanzi FA. Native grasslands at the core: a new paradigm of intensification for the campos of southern south americato increase economic and environmental sustainability. Frontiers in Sustainable Food Systems. 2021; 5:11. https://doi.org/10.3389/ fsufs.2021.547834

22. Valadares Filho SC, Costa e Silva LF, Gionbelli MP, Rotta PP, Marcondes MI, Chizzotti ML, Prados LF. Nutrient requirements of Zebu and crossbreed cattle. 3rd ed. Valadares Filho SC, Costa e Silva LF, Gionbelli MP, Rotta PP, Marcondes MI, Chizzotti ML, Prados LF, editors. Viçosa: UFV. 2016.

23. Da silva SC, Gimenes FMA, Sarmento DOL, Sbrissia AF, Oliveira DE, Hernadez-Garay A, Pires DAV. Grazing behaviour, herbage intake and animal performance of beef cattle heifers on marandu palisade grass subjected to intensities of continuous stocking management. Journal of Agricultural Science. 2013; 151(5):727-739. https://doi.org/10.1017/S0021859612000858

24. Dias MBC, Costa KAP, Severiano EC, Bilego UO, Vilela L, Souza WF, Oliveira IP, Silva ACG. Cattle performance with Brachiaria and Panicum maximum forages in an integrated crop-livestock system. African Journal of Range \& Forage Science. 2021;1-14. https://doi.org/ 10.2989/10220119.2021.1901311

25. Euclides VPB, Macedo MCM, Zimmer AH, Jank L, Oliveira MPD. Avaliação dos capins mombaça e massai sob pastejo. Revista Brasileira de Zootecnia. 2008;37:18-26. https://doi.org/10.1590/ $\underline{\mathrm{S} 1516-35982008000100003}$

26. Euclides VPB, Macedo MCM, Valle CB, Difante GS, Barbosa RA, Cacere ER. Valor nutritivo da forragem e produção animal em pastagens de Brachiaria brizantha. Pesquisa Agropecuária Brasileira. 2009;44(1):98-106. https://doi.org/10.1590/S0100-204X2009000100014

27. Lopes CM, Paciullo DSC, Araújo SAC, Gomide CDM, Morenz MJF, Villela SDJ. Massa de forragem, composição morfológica e valor nutritivo de capim-braquiária submetido a níveis de sombreamento e fertilização. Arquivo Brasileiro de Medicina Veterinária e Zootecnia. 2017;69(1):225-233. https://doi.org/ 10.1590/1678-4162-9201

28. Pereira JM, Rezende CP, Borges, AMF, Homem BGC, Casagrande DR., Macedo TM, Alves BJR, Sant'Anna SAC, Urquiaga S, Boddey RM. Production of beef cattle grazing on Brachiaria brizantha (Marandu grass)Arachis pintoi (forage peanut cv. Belomonte) mixtures exceeded that on grass monocultures fertilized with 120 kg N/ha. Grass and Forage Science. 2020;75(1):28-36. https://doi.org/10.1111/gfs.12463

29. Silva RO, Miotto FRC, Neiva JNM, Da Silva LFFM, De Freitas IB, Araújo VL, Restle J. Effects of increasing nitrogen levels in Mombasa grass on pasture characteristics, chemical composition, and beef cattle 
Production potential of beef cattle in tropical pastures: a review

Barbero R P et al.

performance in the humid tropics of the Amazon. Tropical Animal Health and Production. 2020; 52(6): 3293-3300. https://doi.org/10.1007/s11250-020-02360-0

30. Hodgson J, Silva SC. Options in tropical pasture management. In: Reunião Anual da Sociedade Brasileira de Zootecnia, 39. Anais. Recife: Sociedade Brasileira de Zootecnia. 2002; 180-202.

31. Sinclair TR, Horie T. Leaf nitrogen, photosynthesis, and crop use efficiency: A review. Crop Science. 1989;29:90-97. https://doi.org/10.2135/cropsci1989.0011183X002900010023x

32. Bernardi AWL, Silva DB. Estudo metanalítico da resposta de gramíneas perenes de verão à adubação nitrogenada. Arquivo Brasileiro de Medicina Veterinária e Zootecnia. 2018;70(2):545-553. https://doi.org/ $\underline{10.1590 / 1678-4162-9501}$

33. Canto MW, Filho AB, Moraes A, Hoeschl AR, Gasparino E. Animal production in Tanzania grass swards fertilized with nitrogen. Revista Brasileira de Zootecnia. 2009;38(7):1176-1182. https://doi.org/10.1590/ $\underline{\text { S1516-35982009000700003 }}$

34. Da Silva SC, Nascimento Júnior D. Avanços na pesquisa com plantas forrageiras tropicais em pastagens: características morfofisiológicas e manejo do pastejo. Revista Brasileira. de Zootecnia. 2007,36: 121-138. https://doi.org/10.1590/S1516-35982007001000014

35. Euclides VPB, Montagner DB, Barbosa RA, Nantes NN. Manejo do pastejo de cultivares de Brachiaria brizantha (Hochst) Stapf e de Panicum maximum Jacq. Revista Ceres. 2014; 61:808-818. https://doi.org/ 10.1590/0034-737×201461000006

36. Mott GO. Grazing pressure and the measurement of pasture production. In: International Grassland Congress, 8. 1960;606-611.

37. Carloto MN, Euclides VPB, Montagner DB, Lempp B, Difante GS. Paula CCL. Desempenho animal e características de pasto de capim-xaraés sob diferentes intensidades de pastejo, durante o período das águas. Pesquisa Agropecuária Brasileira. 2011;46(1):97-104. https://doi.org/10.1590/ $\underline{\text { S0100-204X2011000100013 }}$

38. Teixeira FA, Bonomo P, Pires AJV, Silva FF, FriesDD, Hora DS. Produção anual e qualidade de pastagem de Brachiaria decumbens diferida e estratégias de adubação nitrogenada. Acta Scientiarum. Animal Sciences. 2011;33(3):241-248. https://doi.org/10.4025/actascianimsci.v33i3.10194

39. Euclides VPB, Macedo MCM, Zimmer AH, Medeiros RN, Oliveira MP. Características do pasto de capimtanzânia adubado com nitrogênio no final do verão. Pesquisa Agropecuária Brasileira. 2007;42(8):1189-1198. https://doi.org/10.1590/S0100-204X2007000800017

40. Reis RA, Ruggieri AC, Casagrande DR, Pascoa AG. Suplementação da dieta de bovinos de corte como estratégia do manejo das pastagens. Revista Brasileira de Zootecnia. 2009;38:147-159. https://doi.org/ 10.1590/S1516-35982009001300016

41. Moura, AM, Tomich, TR, Pereira LGR, Paciullo DSC, Gomide CAM, Gonçalves, LC. Nutritive value and in 
vitro methane production of Urochloa brizantha cv. Marandu under fixed time or variable stocking cycles. Grass Forage Science 2021;00:1-13. https://doi.org/10.1111/gfs.12509

42. Zanetti MA, Mauro J, Resende L, Schalch F, Miotto CM. Desempenho de novilhos consumindo suplemento mineral proteinado convencional ou com uréia. Revista Brasileira Zootecnia. 2000;29(3):935-939.

43. Barbero RP, de Freitas Barbosa MAA, de Souza Fortaleza AP, Júnior FLM, da Silva LDDF, de Castro LM. Suplementação com fontes proteicas na terminação de novilhas de corte: Estudo bioeconômico. Ciência Animal Brasileira. 2016;17(1):45-50. https://dx.doi.org/10.1590/1089-6891v17i115943

44. Paulino MF, Detmann E, Zervoudakis JT. Suplementos múltiplos para recria e engorda de bovinos em pastejo. In: II Simpósio Produção Gado Corte. Viçosa. 2001;187-232.

45. Barbero RP, Malheiros EB, Nave RLG, Mulliniks JT, Delevatti LM, Koscheck JFW, Romanzini EP, Ferrari AC, Renesto DM, Berchielli TT, Ruggieri AC, Reis, RA. Influence of post-weaning management system during the finishing phase on grasslands or feedlot on aiming to improvement of the beef cattle production. Agricultural Systems. 2017; 153:23-31. https://doi.org/10.1016/j.agsy.2017.01.015

46. Sampaio RL, De Resente, FD, Reis RA, De Oliveira IM, Custódio L, Fernanes RM, Pazdiora, RD, Siqueira, GR. The nutritional interrelationship between the growing and finishing phases in crossbred cattle raised in a tropical system. Tropical Animal Health and Production. 2017; 49:1015-1024.1: 30-37, 2017. https:// doi.org/10.1007/s11250-017-1294-8

47. Branco AF, Moreli G, Jobim CC, Cecato U, Guimarães KC, Teixeira S. Performance of Nellore steers grazing on Panicum maximum Jacq cv. Mombaça receiving chopped sugar cane tops and protein supplementation. Acta Scientiarum. Animal Sciences. 2010,32(4): 455-460. https://doi.org/10.4025/ actascianimsci.v32i4.8142

48. Bento FC, Rovani EA, Mesquita GF, Ruiz LRB, Silva MIL, Moreira PSA, Polizel Neto A, Gomes HFB. Efeito dos níveis de suplementação no desempenho de bovinos em sistema de semi-confinamento. Nativa. 2019;7(6):813-819. http://dx.doi.org/10.31413/nativa.v7i6.7090 